\title{
Systematic Review of Percutaneous Adhesiolysis and Management of Chronic Low Back Pain in Post Lumbar Surgery Syndrome
}

Richard S. Epter, MD1, Standiford Helm II, MD², Salim M. Hayek, MD, PhD, Ramsin M. Benyamin, MD ${ }^{4}$, Howard S. Smith, MD ${ }^{5}$, and Salahadin Abdi, MD, $\mathrm{PhD}^{6}$

From: ${ }^{1}$ Augusta Pain Center, Augusta, GA; ${ }^{2}$ Pacific Coast Pain Management Center, Laguna Hills, CA; ${ }^{3}$ University Hospitals of Cleveland and Outcomes Research Consortium, Cleveland, $\mathrm{OH} ;{ }^{4}$ Millennium Pain Center

Bloomington, IL; ${ }^{5}$ Albany Medical College Albany, NY; and ${ }^{6}$ University Of Miami, Miller School Of Medicine, Miami, FL

Dr. Epter is Medical Director, Augusta Pain Center, Augusta, GA; Assistant Clinical Professor of Anesthesiology, Medical College of Georgia School of Medicine, Augusta, GA. Dr. Helm is a

Medical Director, Pacific Coast Pain Management Center, Laguna Hills,

CA. Dr. Hayek is Chief of the Division

of Pain Medicine, Department of Anesthesiology, University Hospitals of Cleveland, Cleveland, $\mathrm{OH}$; and a member of the Outcomes Research Consortium, Cleveland, $\mathrm{OH}$. Dr. Benyamin is Medical Director, Millennium Pain Center,

Bloomington, IL, and Clinical Assistant Professor of Surgery, College of Medicine, University of Illinois, Urbana-Champaign,

IL. Dr. Smith is Associate Professor and Academic Director of Pain Management for Albany Medical College Department

of Anesthesiology, Albany, NY. Dr. Abdi

is Professor and Chief, Division of Pain Medicine, Department of Anesthesiology, Perioperative Medicine and Pain Management, University of Miami, Miller School of Medicine, Miami, FL. Address correspondence: Richard Epter, MD Augusta Pain Center P.O. Box 211839 Augusta GA 30917-1839 E-mail: paindoc727@aol.com

Disclaimer: There was no external funding in the preparation of this manuscript. Conflict of interest: None.

Manuscript received: $11 / 07 / 2008$ Revised manuscript received:01/18/2009 Accepted for publication: 01/20/2009

Free full manuscrip www.painphysicianjournal.com
Background: Post lumbar surgery syndrome or failed back surgery syndrome with persistent pain continues to increase over the years. The speculated causes of post lumbar laminectomy syndrome include acquired stenosis, epidural fibrosis, arachnoiditis, radiculopathy, and recurrent disc herniation. Epidural fibrosis may account for as much as $20 \%$ to $36 \%$ of all cases of failed back surgery syndrome. Percutaneous epidural adhesiolysis has been employed in interventional pain management in the treatment of chronic, refractory low back and lower extremity pain after back surgery.

Study Design: A systematic review of randomized trials and observational studies.

Objective: To evaluate the effectiveness of percutaneous adhesiolysis in managing chronic low back and lower extremity pain due to post lumbar surgery syndrome.

Methods: A comprehensive literature search was conducted utilizing electronic databases, as well as systematic reviews and cross references from 1966 through December 2008.

The quality of individual articles used in this analysis was assessed by modified Cochrane review criteria for randomized trials and the Agency for Healthcare Research and Quality (AHRQ) criteria for assessment of observational studies.

Clinical relevance was evaluated using 5 questions according to the criteria recommended by the Cochrane Review Back Group.

Analysis was conducted using 5 levels of evidence, ranging from Level I to III, with 3 subcategories in Level II.

Outcome Parameters: The primary outcome measure was pain relief (short-term relief of at least 6 months and long-term relief of more than 6 months). Secondary outcome measures were improvement in functional status, psychological status, return to work, and change in opioid intake.

Results: Of the 13 studies considered for inclusion, 3 randomized trials and 4 observational studies met the inclusion criteria for methodologic quality assessment and evidence synthesis based on methodologic quality scores of 50 or more. Evidence of percutaneous adhesiolysis in the management of chronic low back pain in post-lumbar surgery syndrome is Level I to Level II1, with evidence derived from 3 randomized trials.

Limitations: There is a paucity of efficacy and pragmatic trials. No trials have been published after 2006

Conclusion: The indicated level of evidence for percutaneous adhesiolysis is Level I or II-1 based on the US Preventative Services Task Force (USPSTF) criteria.

Key words: Chronic low back pain, post lumbar surgery syndrome, post surgery syndrome, failed back surgery syndrome, spinal stenosis, epidural fibrosis, interventional techniques, percutaneous adhesiolysis, hypertonic saline neurolysis

Pain Physician 2009; 12:361-378 
ntervertebral disc herniation, spinal stenosis, and degenerative spondylolisthesis with stenosis are the 3 most common diagnoses of low back and leg symptoms for which surgery is performed $(1,2)$. Post surgery syndrome and other synonyms such as post lumbar laminectomy syndrome or failed back surgery syndrome represent a cluster of syndromes following spine surgery wherein the expectations of the patient and spine surgeon are not met. Persistent pain following lumbar surgery is common (3-14). Since discectomies and spinal fusions have been increasing exponentially, it appears that the prevalence of persistent pain following lumbar spine surgery continues to increase (15-21). Further, the prevalence of chronic persistent pain along with seeking care for that pain have been reported to be increasing $(22,23)$.

Hypothesized causes of post laminectomy syndrome include acquired stenosis, adjacent segment degeneration, internal disc disruption, recurrent disc herniation, retained disc fragment, spondylolisthesis, epidural or intraneural fibrosis, degenerative disc disease, radiculopathy, facet joint pain, sacroiliac joint pain, discitis, arachnoiditis, pseudoarthritis, segmental instability, and others (3-5,9-11,24-31). However, among multiple etiologies, epidural fibrosis, discogenic pain, recurrent disc herniation, and spinal stenosis can be treated with either caudal epidural injections or percutaneous adhesiolysis in patients nonresponsive to caudal epidural injections (24-28,32-40). However, facet joint and sacroiliac joint pain may be treated with other interventional techniques (41-46). Epidural fibrosis may account for as much as $20 \%$ to $36 \%$ of all cases of failed back surgery syndrome $(9,10,24$ $28,47,48)$. A correlation between peridural scarring and radicular pain $(9,49-51)$ and poor clinical outcomes (52) has been reported by some authors, while others (53-55) have contradicted the role of epidural fibrosis as a causative factor.

Animal models of post lumbar laminectomy syndrome demonstrate paraspinal muscle spasms, tail contractures, spontaneous pain behaviors, tactile allodynia, epidural and perineural scarring, and nerve root adherence to the underlying disc and pedicle (53-58). While, a 2005 Cochrane Review found that paucity and heterogeneity of evidence limited the conclusions regarding surgical efficacy for spinal stenosis (59). Weinstein et al (6) as part of the Spine Patient Outcomes Research Trial (SPORT) reported on 2-year outcomes of patients with spinal stenosis without degenerative spondylosis with the conclusion that in the combined as treated analysis, patients who underwent surgery showed significantly more improvement in all primary outcomes than did patients who were treated non-surgically. However, a comparison of results by Huntoon and Buizgher (60) showed similar outcomes with caudal epidural injections.

Epidural injection for managing chronic low back pain is one of the most commonly performed interventions in the United States with exponential growth and geographic variations (26,32-38,60-66). However, in the case of postsurgery syndrome and spinal stenosis only a moderate proportion of patients showed improvement in pain and functional level with epidural injections $(26,38,67,68)$. Two recent studies evaluating the effectiveness of caudal epidural injections secondary to post surgery syndrome and spinal stenosis showed encouraging results $(32,33)$ even though injections were inferior when used to treat chronic low back pain secondary to disc herniation or discogenic pain without disc herniation $(34,35)$. However, the evidence derived from percutaneous adhesiolysis procedures has been moderate to strong in managing pain of post surgery syndrome $(24,26,27)$. Percutaneous epidural adhesiolysis has been employed in interventional pain management in the management of chronic, refractory low back and lower extremity pain $(24-28,39,69-77)$ with the purpose of eliminating scar tissue and assuring the delivery of high concentrations of injected drugs to targeted areas.

The latest systematic review evaluating the effectiveness of epidural adhesiolysis was published in January 2007 (24) and it must also be noted that a significant proportion of systematic reviews are outdated within a 2-4 year period, specifically in assessment of emerging specialties (78). This systematic review was undertaken to provide a current evaluation of the effectiveness of percutaneous adhesiolysis is postsurgery syndrome.

\section{Methods}

\section{Literature Search}

A comprehensive literature search was conducted using multiple databases including PubMed and EMBASE from 1966 through December 2008, Cochrane database, Clinical Trial Registry, systematic reviews, narrative reviews, and cross-references to the reviews published in the English language. 
The search strategy emphasized chronic low back pain secondary to post surgery syndrome with a focus on percutaneous adhesiolysis. The search terminology included post lumbar surgery syndrome, failed back surgery syndrome, epidural fibrosis, chronic low back pain, adhesiolysis, epidural neuroplasty, epidural neurolysis, lysis of adhesions, percutaneous adhesiolysis, hypertonic and saline neurolysis.

\section{Selection Criteria}

The review focused on randomized trials, observational studies, and reports of complications. The population of interest was patients suffering with chronic intractable low back pain with or without radicular findings for at least 6 months. Only percutaneous adhesiolysis procedures were evaluated. All the studies providing appropriate management with outcome evaluations of 6 months or longer and statistical evaluations were reviewed. Reports without appropriate diagnosis, non-systematic reviews, book chapters, and case reports were excluded.

\section{Outcome Parameters}

The primary outcome measure was pain relief (short-term relief $\leq 6$ months and long-term $>6$ months). Secondary outcome measures were improvement in functional status, psychological status, return to work, and change in opioid intake.

\section{Review Criteria}

Each study was evaluated by 2 physicians for stated criteria and any disagreements were resolved by a third physician.

If there was any conflict of interest with the reviewed manuscripts, the involved authors did not review the manuscripts for quality assessment, clinical relevance, evidence synthesis, or grading of evidence.

\section{Methodologic Quality Assessment}

The quality of each individual article used in this analysis was assessed by modified Cochrane review criteria with weighted scores (79) for randomized trials and the Agency for Healthcare Research and Quality (AHRQ) quality criteria for assessment of observational studies (80). Consensus-based weighted scoring developed by Koes et al (79) and Nelemans et al (81) was used for randomized trials and was adapted by the guidelines committee of the American Society of Interventional Pain Physicians (ASIPP) for use with ob- servational studies and has been utilized in multiple; previous evaluations $(36,40,42,43,82-90)$.

Only the studies scoring at least 50 of 100 on weighted scoring criteria were utilized for analysis.

Observational studies were only included in the evidence synthesis if there were less than 4 randomized trials meeting the inclusion criteria.

\section{Clinical Relevance}

The clinical relevance of the included studies was evaluated according to 5 questions recommended by the Cochrane Back Review Group $(91,92)$. Each question was scored positive (+) if the clinical relevance item was met, negative (-) if the item was not met, and unclear (?) if data were not available to answer the question.

In the recent Cochrane review of "Injection Therapy for Subacute and Chronic Low Back Pain" (91) the authors considered a $20 \%$ improvement in pain scores (93) and a $10 \%$ improvement in functioning outcomes (94) to be clinically important. The current study utilized stricter criteria than general systematic reviews and previous systematic reviews. Any relief of 6 months or less was considered as short-term, whereas Cochrane reviews (91) and others have considered 6 weeks as short-term and longer than 6 weeks as long-term. We also utilized methodologic quality assessment criteria (91) for minimum inclusion, thus this systematic review is expected to provide robust results with stricter criteria. Further, in contrast to many other systematic reviews, in this systematic review, observational studies with scores of 50 or more on a scale of 0 - 100 based on AHRQ criteria were included. This improves the generalizability of the systematic review as well as the intervention (95-99).

\section{Prior Treatment Criteria}

Patients must have undergone non-interventional treatment (physical therapy, oral medications) or prior fluoroscopically guided epidural steroid injections.

\section{Analysis of Evidence}

Analysis was conducted using 5 levels of evidence, ranging from Level I to III with 3 subcategories in Level II, as illustrated in Table 1 (100).

\section{Recommendations}

Grading recommendations were based on Guyatt et al's criteria as illustrated in Table 2 (101). 
Table 1. Modified quality of evidence developed by USPSTF.

\begin{tabular}{|l|l||}
\hline I: & Evidence obtained from at least one properly randomized controlled trial \\
\hline II-1: & Evidence obtained from well-designed controlled trials without randomization \\
\hline II-2: & Evidence obtained from well-designed cohort or case-control analytic studies, preferably from more than one center or research group \\
\hline II-3: & $\begin{array}{l}\text { Evidence obtained from multiple time series with or without the intervention. Dramatic results in uncontrolled experiments (such as the } \\
\text { results of the introduction of penicillin treatment in the 1940s) could also be regarded as this type of evidence }\end{array}$ \\
\hline III: & Opinions of respected authorities, based on clinical experience descriptive studies and case reports or reports of expert committees \\
\hline
\end{tabular}

Adapted and modified from the U.S. Preventive Services Task Force (USPSTF) (100).

Table 2. Grading recommendations.

\begin{tabular}{|c|c|c|c|}
\hline $\begin{array}{c}\text { Grade of Recommendation/ } \\
\text { Description }\end{array}$ & $\begin{array}{c}\text { Benefit vs Risk and } \\
\text { Burdens }\end{array}$ & $\begin{array}{c}\text { Methodological Quality of } \\
\text { Supporting Evidence }\end{array}$ & Implications \\
\hline $\begin{array}{l}1 \mathrm{~A} / \text { strong recommendation, } \\
\text { high-quality evidence }\end{array}$ & $\begin{array}{l}\text { Benefits clearly outweigh } \\
\text { risk and burdens, or vice } \\
\text { versa }\end{array}$ & $\begin{array}{l}\text { RCTs without important limitations or } \\
\text { overwhelming evidence from observa- } \\
\text { tional studies }\end{array}$ & $\begin{array}{l}\text { Strong recommendation, can ap- } \\
\text { ply to most patients in most cir- } \\
\text { cumstances without reservation }\end{array}$ \\
\hline $\begin{array}{l}1 \mathrm{~B} / \text { strong recommendation, } \\
\text { moderate quality evidence }\end{array}$ & $\begin{array}{l}\text { Benefits clearly outweigh } \\
\text { risk and burdens, or vice } \\
\text { versa }\end{array}$ & $\begin{array}{l}\text { RCTs with important limitations (incon- } \\
\text { sistent results, methodological flaws, indi- } \\
\text { rect, or imprecise) or exceptionally strong } \\
\text { evidence from observational studies }\end{array}$ & $\begin{array}{l}\text { Strong recommendation, can ap- } \\
\text { ply to most patients in most cir- } \\
\text { cumstances without reservation }\end{array}$ \\
\hline $\begin{array}{l}\text { 1C/strong recommendation, } \\
\text { low-quality or very low-quality } \\
\text { evidence }\end{array}$ & $\begin{array}{l}\text { Benefits clearly outweigh } \\
\text { risk and burdens, or vice } \\
\text { versa }\end{array}$ & Observational studies or case series & $\begin{array}{l}\text { Strong recommendation but } \\
\text { may change when higher quality } \\
\text { evidence becomes available }\end{array}$ \\
\hline $\begin{array}{l}\text { 2A/weak recommendation, high- } \\
\text { quality evidence }\end{array}$ & $\begin{array}{l}\text { Benefits closely balanced } \\
\text { with risks and burden }\end{array}$ & $\begin{array}{l}\text { RCTs without important limitations or } \\
\text { overwhelming evidence from observa- } \\
\text { tional studies }\end{array}$ & $\begin{array}{l}\text { Weak recommendation, best } \\
\text { action may differ depending on } \\
\text { circumstances or patients' or } \\
\text { societal values }\end{array}$ \\
\hline $\begin{array}{l}2 \mathrm{~B} / \text { weak recommendation, mod- } \\
\text { erate-quality evidence }\end{array}$ & $\begin{array}{l}\text { Benefits closely balanced } \\
\text { with risks and burden }\end{array}$ & $\begin{array}{l}\text { RCTs with important limitations (incon- } \\
\text { sistent results, methodological flaws, indi- } \\
\text { rect, or imprecise) or exceptionally strong } \\
\text { evidence from observational studies }\end{array}$ & $\begin{array}{l}\text { Weak recommendation, best } \\
\text { action may differ depending on } \\
\text { circumstances or patients' or } \\
\text { societal values }\end{array}$ \\
\hline $\begin{array}{l}2 \mathrm{C} / \text { weak recommendation, } \\
\text { low-quality or very low-quality } \\
\text { evidence }\end{array}$ & $\begin{array}{l}\text { Uncertainty in the esti- } \\
\text { mates of benefits, risks, } \\
\text { and burden; benefits, risk, } \\
\text { and burden may be closely } \\
\text { balanced }\end{array}$ & Observational studies or case series & $\begin{array}{l}\text { Very weak recommendations; } \\
\text { other alternatives may be equally } \\
\text { reasonable }\end{array}$ \\
\hline
\end{tabular}

Adapted from Guyatt $\mathrm{G}$ et al. Grading strength of recommendations and quality of evidence in clinical guidelines. Report from an American College of Chest Physicians task force. Chest 2006; 129:174-181 (101).

\section{Outcomes of the Studies}

A study was judged to be positive if the percutaneous adhesiolysis was clinically relevant and effective, either with a placebo control or active control in randomized trials. This indicates that the difference in the effect for the primary outcome measure was statistically significant on the conventional $5 \%$ level. In a negative study, no difference between the study treatment or no improvement from baseline was reported. Further, the outcomes were judged at the reference point with positive or negative results reported at 3 months, 6 months, and one year.

For observational studies, a study was judged to be positive if the percutaneous adhesiolysis was ef- fective, with outcomes reported at the reference point with positive or negative results at 3 months, 6 months, and one year.

\section{Results}

A literature search was carried out for percutaneous adhesiolysis as shown in Fig. 1.

Our search strategy yielded multiple studies evaluating the effectiveness of percutaneous adhesiolysis. These included 3 systematic reviews $(24,27,102)$, one technology assessment (103), and 13 studies (69-77,104-107). Of these, there were 5 randomized trials $(69,72-75)$, and 8 observational studies $(70,71,76,77,104-107)$. 


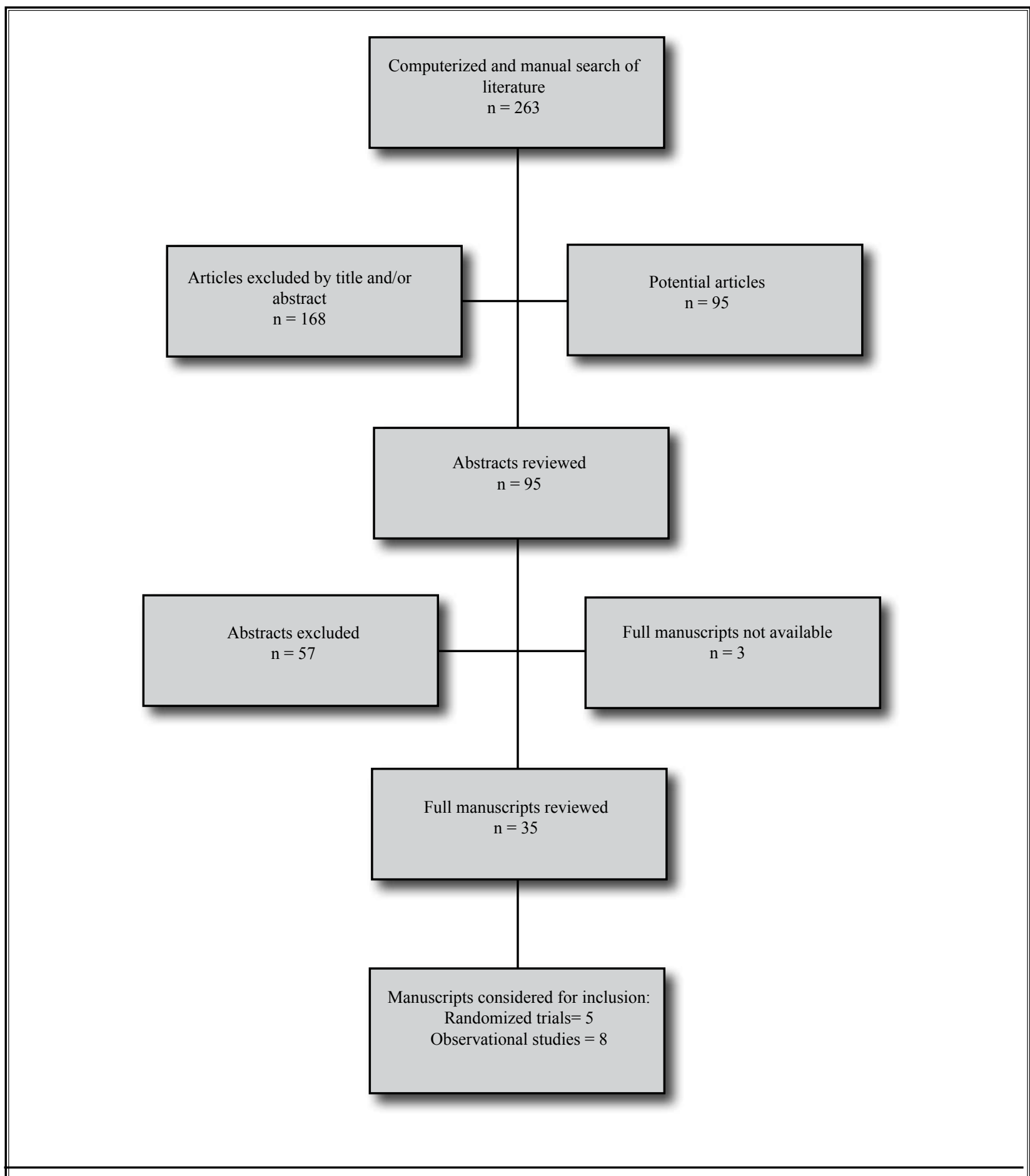

Fig. 1. The flow diagram illustrating randomized trials and observational studies evaluating percutaneous adhesiolysis 


\section{Randomized Trials}

\section{Methodologic Quality Assessment:}

Of the 5 randomized trials $(69,72-75), 3$ of them met criteria $(69,72,74)$, one was a duplication $(73)$, and another one was a quasi randomized study (75), considered to be an observational study.

All 3 trials included heterogenous population.

Methodologic quality assessment criteria are illustrated in Table 3 showing all the randomized clinical trials evaluating the effectiveness of percutaneous adhesiolysis. The quality assessment criteria ranged from 55 to 74 with all 3 trials meeting inclusion criteria for evidence synthesis.

Table 4 illustrates the clinical relevance of the randomized trials.
Clinical Relevance Assessment

All 3 studies met clinical relevance criteria $(69,72,74)$.

\section{Study Characteristics}

Study characteristics of published randomized trials of percutaneous adhesiolysis are illustrated in Table 5.

\section{Observational Studies}

\section{Methodologic Quality Assessment}

There were 8 observational studies considered for inclusion $(70,71,76,77,105-108)$ with the addition of one study (75) which failed to the meet design criteria of a randomized trial, and thus was considered obser-

Table 3. Methodological assessment of randomized clinical trials evaluating effectiveness of adhesiolysis.

\begin{tabular}{|c|c|c|c|c|c|}
\hline \multicolumn{2}{|r|}{ Criterion } & $\begin{array}{l}\text { Weighted Score } \\
\text { (points) }\end{array}$ & $\begin{array}{l}\text { Manchikanti et } \\
\quad \text { al (74) }\end{array}$ & $\begin{array}{c}\text { Heavner et al } \\
(72)\end{array}$ & $\begin{array}{l}\text { Veihelmann et } \\
\text { al (69) }\end{array}$ \\
\hline \multicolumn{6}{|c|}{ Study Population } \\
\hline A & Homogeneity & 2 & 2 & 2 & 2 \\
\hline B & Comparability of relevant baseline characteristics & 5 & 5 & 5 & 5 \\
\hline $\mathrm{C}$ & Randomization procedure adequate & 4 & 4 & 4 & 2 \\
\hline $\mathrm{D}$ & Drop-outs described for each study group separately & 3 & 3 & 3 & 3 \\
\hline \multirow[t]{2}{*}{$\mathrm{E}$} & $\leq 20 \%$ loss for follow-up & 2 & - & - & - \\
\hline & $\leq 10 \%$ loss for follow-up & 2 & - & - & - \\
\hline \multirow[t]{2}{*}{$\mathrm{F}$} & $>50$ subject in the smallest group & 8 & - & - & - \\
\hline & $>100$ subjects in the smallest group & 9 & - & - & - \\
\hline \multicolumn{6}{|c|}{ Interventions } \\
\hline G & Interventions included in protocol and described & 10 & 10 & 10 & 10 \\
\hline $\mathrm{H}$ & Pragmatic study & 5 & 5 & 5 & 5 \\
\hline I & Co-interventions avoided or similar & 5 & 5 & 5 & 5 \\
\hline $\mathrm{J}$ & Placebo-controlled & 5 & - & - & - \\
\hline \multicolumn{6}{|c|}{ Effect } \\
\hline $\mathrm{K}$ & Patients blinded & 5 & 5 & 5 & - \\
\hline $\mathrm{L}$ & Outcome measures relevant & 10 & 10 & 10 & 10 \\
\hline M & Blinded outcome assessments & 10 & 10 & 10 & 3 \\
\hline $\mathrm{N}$ & Follow-up period adequate & 5 & 5 & 5 & 5 \\
\hline \multicolumn{6}{|c|}{ Data presentation and analysis } \\
\hline $\mathrm{O}$ & Intention-to-treat analysis & 5 & 5 & - & - \\
\hline $\mathrm{P}$ & $\begin{array}{l}\text { Frequencies of most important outcomes presented } \\
\text { for each treatment group }\end{array}$ & 5 & 5 & 5 & 5 \\
\hline \multicolumn{2}{|c|}{ TOTAL SCORE } & 100 & 74 & 69 & 55 \\
\hline
\end{tabular}

Methodological criteria and scoring adapted from Koes BW et al. Efficacy of epidural steroid injections for low-back pain and sciatica: A systematic review of randomized clinical trials. Pain 1995; 63:279-288 (79). 
Table 4. Clinical relevance of randomized clinical trials evaluating the effectiveness of percutaneous adhesiolysis.

\begin{tabular}{|l|c|c|c|}
\hline \hline & $\begin{array}{c}\text { Manchikanti et } \\
\text { al (74) }\end{array}$ & $\begin{array}{c}\text { Heavner et al } \\
\text { (72) }\end{array}$ & $\begin{array}{c}\text { Veihelmann } \\
\text { et al (69) }\end{array}$ \\
\hline $\begin{array}{l}\text { A) Are the patients described in detail so that you can decide whether they are compa- } \\
\text { rable to those that you see in your practice? }\end{array}$ & + & + & + \\
\hline $\begin{array}{l}\text { B) Are the interventions and treatment settings described well enough so that you can } \\
\text { provide the same for your patients? }\end{array}$ & + & + & + \\
\hline C) Were all clinically relevant outcomes measured and reported? & + & + & + \\
\hline D) Is the size of the effect clinically important? & + & $?$ & + \\
\hline E) Are the likely treatment benefits worth the potential harms? & + & + & + \\
\hline \multicolumn{1}{|c|}{ TOTAL CRITERIA MET } & $5 / 5$ & $4 / 5$ & $5 / 5$ \\
\hline
\end{tabular}

+ = positive; - = negative; ? = unclear

Scoring adapted from Staal JB et al. Injection therapy for subacute and chronic low-back pain. Cochrane Database Syst Rev 2008; 3:CD001824 (91).

Table 5. Results of randomized trials of percutaneous adhesiolysis.

\begin{tabular}{|c|c|c|c|c|c|}
\hline Study & Participants & Intervention(s) & Outcome(s) & Result(s) & $\begin{array}{l}\text { Conclusion(s) } \\
\text { Short-term } \\
\text { relief } \leq 6 \mathrm{mos} \\
\text { Long-term } \\
\text { relief }>6 \mathrm{mos}\end{array}$ \\
\hline $\begin{array}{l}\text { Veihelmann } \\
\text { et al } 2006 \\
(69)\end{array}$ & $\begin{array}{l}99 \text { patients with chronic low } \\
\text { back pain and sciatica ( } 13 \text { with } \\
\text { prior back surgery). Nerve root } \\
\text { compromise confirmed by MRI } \\
\text { and CT. } 52 \text { patients treated with } \\
\text { physiotherapy (PT) (control) } \\
\text { ( } 5 \text { prior surgery) } 47 \text { underwent } \\
\text { epidural neuroplasty (percutane- } \\
\text { ous adhesiolysis) } 8 \text { prior surgery } \\
\text { PT patients could cross over after } \\
3 \text { months ( } 12 \text { patients crossed } \\
\text { over). }\end{array}$ & $\begin{array}{l}\text { Group I underwent physical } \\
\text { therapy (no description of } \\
\text { specific exercises), Group } \\
\text { II underwent percutaneous } \\
\text { adhesiolysis -Catheter placed } \\
\text { through sacral hiatus to level } \\
\text { of pathology after epiduro- } \\
\text { gram to confirm position. } 9 \\
\text { mL ropivacaine and } 40 \mathrm{mg} \\
\text { triamcinolone catheter } \\
\text { secured, } 30 \text { minutes later, } 10 \\
\text { mL of } 10 \% \text { saline instilled, } \\
\text { Unclear whether this was a } 1 \\
\text { day or } 3 \text { day protocol. }\end{array}$ & $\begin{array}{l}\text { Timing: } 3 \text { months, } \\
6 \text { months, } 12 \\
\text { months. Outcome } \\
\text { measures: VAS } \\
\text { back, VAS leg, } \\
\text { Oswestry disability } \\
\text { score, Gerbersha- } \\
\text { gen score, analgesic } \\
\text { score. }\end{array}$ & $\begin{array}{l}\text { Intention to treat } \\
\text { analysis was per- } \\
\text { formed. Among } \\
\text { the adhesiolysis } \\
\text { patients, there was a } \\
\text { significant decrease } \\
\text { in VAS and Oswestry } \\
\text { scores at } 1,3,6 \text {, and } \\
12 \text { months. } 28 \text { adhe- } \\
\text { siolysis patients were } \\
\text { able to decrease I' } \\
\text { Gerbershagen grade } \\
\text { compared to } 2 \text { PT } \\
\text { patients. }\end{array}$ & $\begin{array}{l}\text { Positive short- } \\
\text { and long-term } \\
\text { relief. }\end{array}$ \\
\hline $\begin{array}{l}\text { Manchikanti } \\
\text { et al } 2004 \\
(74)\end{array}$ & $\begin{array}{l}75 \text { patients were evaluated. } 25 \text { pa- } \\
\text { tients in Group I served as controls } \\
\text { and were treated with catheteriza- } \\
\text { tion but no adhesiolysis. } 25 \text { patients } \\
\text { in Group II were treated with } \\
\text { catheterization, and adhesiolysis, } \\
\text { followed by injection of local anes- } \\
\text { thetic, normal saline, and steroid. } \\
25 \text { patients in Group III, treatment } \\
\text { consisted of adhesiolysis followed } \\
\text { by injection of local anesthetic, } \\
\text { hypertonic saline, and steroid. }\end{array}$ & $\begin{array}{l}\text { Experimental groups: Ad- } \\
\text { hesiolysis, hypertonic saline } \\
\text { neurolysis, steroid and local } \\
\text { anesthetic, and adhesiolysis, } \\
\text { normal saline, steroid. Con- } \\
\text { trol group: Catheterization } \\
\text { and no adhesiolysis. }\end{array}$ & $\begin{array}{l}\text { Timing: } 3 \text { months, } \\
6 \text { months, and } 12 \\
\text { months. Out- } \\
\text { come measures: } \\
\text { VAS pain scale, } \\
\text { Oswestry Disability } \\
\text { Index 2.0, work sta- } \\
\text { tus, opioid intake, } \\
\text { range of motion } \\
\text { measurements, } \\
\text { and psychological } \\
\text { evaluation by P-3. }\end{array}$ & $\begin{array}{l}72 \% \text { of patients in } \\
\text { Group III (adhesioly- } \\
\text { sis and hypertonic } \\
\text { neurolysis), } 60 \% \text { of } \\
\text { patients in Group II } \\
\text { (adhesiolysis only), } \\
\text { compared to } 0 \% \text { in } \\
\text { Group I (control) } \\
\text { showed significant } \\
\text { improvement at } 12- \\
\text { month follow-up. }\end{array}$ & $\begin{array}{l}\text { Positive short- } \\
\text { and long-term } \\
\text { relief. }\end{array}$ \\
\hline $\begin{array}{l}\text { Heavner et al } \\
1999(72)\end{array}$ & $\begin{array}{l}59 \text { patients with chronic intracta- } \\
\text { ble low back pain. All the patients } \\
\text { failed conservative management, } \\
\text { along with fluoroscopically di- } \\
\text { rected epidural steroid injections. }\end{array}$ & $\begin{array}{l}\text { Group I: hypertonic saline } \\
\text { plus hyaluronidase. Group } \\
\text { II: hypertonic saline Group } \\
\text { III: isotonic saline ( } 0.9 \% \\
\mathrm{NaCl}) \text {. Group IV: isotonic } \\
\text { saline plus hyaluronidase. }\end{array}$ & $\begin{array}{l}\text { Timing: } 4 \text { weeks, } 3 \\
\text { months, } 6 \text { months, } \\
\text { and } 12 \text { months. } \\
\text { Outcome measure: } \\
\text { Pain relief. }\end{array}$ & $\begin{array}{l}\text { Initially } 83 \% \text { of the } \\
\text { patients showed } \\
\text { significant improve- } \\
\text { ment compared to } \\
49 \% \text { of the patients at } \\
3 \text { months, } 43 \% \text { of the } \\
\text { patients at } 6 \text { months, } \\
\text { and } 49 \% \text { of the pa- } \\
\text { tients at } 12 \text { months. }\end{array}$ & $\begin{array}{l}\text { Positive short- } \\
\text { and long-term } \\
\text { relief. }\end{array}$ \\
\hline
\end{tabular}


vational. Of the 9 studies, 4 met criteria for inclusion for methodologic quality assessment $(71,75-77)$. Meth- odologic quality assessment criteria are illustrated in Table 6. Methodologic quality assessment showed

Table 6. Illustration of methodologic assessment of observational studies of percutaneous adhesiolysis.

\begin{tabular}{|c|c|c|c|c|c|}
\hline CRITERION & $\begin{array}{c}\text { Weighted } \\
\text { Score } \\
\text { (points) }\end{array}$ & $\begin{array}{c}\text { Manchikanti } \\
\text { et al (75) }\end{array}$ & $\begin{array}{c}\text { Manchikanti } \\
\text { et al (77) }\end{array}$ & $\begin{array}{c}\text { Manchikanti } \\
\text { et al (76) }\end{array}$ & $\begin{array}{c}\text { Gerdesmeyer } \\
\text { et al (71) }\end{array}$ \\
\hline 1. Study Question & 2 & 2 & 2 & 2 & 2 \\
\hline \multicolumn{6}{|l|}{ - Clearly focused and appropriate question } \\
\hline 2. Study Population & 8 & 5 & 5 & 5 & 5 \\
\hline - Description of study population & 5 & 5 & 5 & 5 & 5 \\
\hline - Sample size justification & 3 & - & - & - & - \\
\hline 3. Comparability of Subjects & 22 & 19 & 14 & 14 & 8 \\
\hline - Specific inclusion/exclusion criteria for all groups & 5 & 5 & 5 & 5 & 5 \\
\hline - Criteria applied equally to all groups & 3 & 3 & 3 & 3 & - \\
\hline $\begin{array}{l}\text { - Comparability of groups at baseline with regard to disease } \\
\text { status and prognostic factors }\end{array}$ & 3 & 3 & 3 & 3 & - \\
\hline $\begin{array}{l}\text { - Study groups comparable to non-participants with regard } \\
\text { to confounding factors }\end{array}$ & 3 & - & - & - & - \\
\hline - Use of concurrent controls & 5 & 5 & - & - & - \\
\hline - Comparability of follow-up among groups at each assessment & 3 & 3 & 3 & 3 & 3 \\
\hline 4. Exposure or Intervention & 11 & 11 & 11 & 11 & 11 \\
\hline - Clear definition of exposure & 5 & 5 & 5 & 5 & 5 \\
\hline - Measurement method standard, valid and reliable & 3 & 3 & 3 & 3 & 3 \\
\hline - Exposure measured equally in all study groups & 3 & 3 & 3 & 3 & 3 \\
\hline 5. Outcome measures & 20 & 15 & 15 & 15 & 10 \\
\hline - Primary/secondary outcomes clearly defined & 5 & 5 & 5 & 5 & 5 \\
\hline - Outcomes assessed blind to exposure or intervention & 5 & - & - & - & - \\
\hline - Method of outcome assessment standard, valid and reliable & 5 & 5 & 5 & 5 & 5 \\
\hline - Length of follow-up adequate for question & 5 & 5 & 5 & 5 & - \\
\hline 6. Statistical Analysis & 19 & 10 & 10 & 5 & 8 \\
\hline - Statistical tests appropriate & 5 & 5 & 5 & 5 & 5 \\
\hline - Multiple comparisons taken into consideration & 3 & 3 & 3 & - & 3 \\
\hline - Modeling and multivariate techniques appropriate & 2 & 2 & 2 & - & - \\
\hline - Power calculation provided & 2 & - & - & - & - \\
\hline - Assessment of confounding & 5 & - & - & - & - \\
\hline - Dose-response assessment if appropriate & 2 & - & - & - & - \\
\hline 7. Results & 8 & 8 & 8 & 6 & 3 \\
\hline $\begin{array}{l}\text { - Measure of effect for outcomes and appropriate measure } \\
\text { of precision }\end{array}$ & 5 & 5 & 5 & 3 & 3 \\
\hline - Adequacy of follow-up for each study group & 3 & 3 & 3 & 3 & - \\
\hline 8. Discussion & 5 & 5 & 5 & 5 & 5 \\
\hline \multicolumn{6}{|l|}{$\begin{array}{l}\text { - Conclusions supported by results with possible biases and } \\
\text { limitations taken into consideration }\end{array}$} \\
\hline 9. Funding or Sponsorship & 5 & 5 & 5 & 5 & 2 \\
\hline \multicolumn{6}{|l|}{ - Type and sources of support for study } \\
\hline TOTAL SCORE & 100 & 80 & 75 & 68 & 54 \\
\hline
\end{tabular}

Adapted and modified from West S et al. Systems to Rate the Strength of Scientific Evidence, Evidence Report, Technology Assessment No. 47. AHRQ Publication No. 02-E016 (80). 
scores of 54 to 80 . Five studies failed to meet the inclusion criteria: one study (105) evaluated the role of adhesiolysis in refractory spinal stenosis; the second study (106) evaluated the effectiveness of transforaminal ventral epidural adhesiolysis; the third study (107) described the relevance of epidurography and epidural adhesiolysis with a flimsy catheter, which was considered as adhesiolysis; the fourth study (108) was a case report utilizing a craniocaudal lateral intralaminar approach; and the fifth study (70) was a shortterm follow-up.

Among the observational studies meeting the inclusion criteria for evidence synthesis, one study (77) included only post laminectomy patients, and 3 studies included heterogeneous populations, which also included post laminectomy syndrome patients $(71,75,76)$.

\section{Study Characteristics}

Study characteristics of all observational studies are illustrated in Table 7.

Gerdesmeyer et al (71), evaluated 98 patients initially and of these, 61 patients met inclusion criteria. Based on the review, even though specifically not mentioned, it appears that patients with disc herniation, as well as post lumbar laminectomy syndrome were included.

Among the 2 observational reports included $(76,77)$, patient demographics were described in both studies. In one of the studies, the proportion of patients in Group II was 37\% compared to 65\% in Group I (76). In addition, work-related injury was lower in Group II (30\%) than Group I (50\%). Duration of pain was also longer in Group II compared to Group I. Patients in Group I received adhesiolysis and hypertonic saline neurolysis on 2 consecutive days with the catheter in place for the second day. In contrast, Group II patients received a single day procedure with percutaneous adhesiolysis, as well as hypertonic saline neurolysis. In one study (77), only patients with post lumbar laminectomy were included.

Manchikanti et al (75) studied 45 patients with 30 patients in the treatment group and 15 patients in the conservative management group with one-day adhesiolysis showing improvement with pain relief in $93 \%$ of the patients at 6 months and $47 \%$ of the patients at 1 year. However, procedures were repeated 1 to 3 times. Patients in the treatment group also showed significant improvement in functional and psychological status. The results of this study have not been considered significant, as it was neither blinded, nor did it include a control group undergoing placebo injections.

\section{Descriptive Characteristics}

All the studies included in the evidence synthesis described patient baseline characteristics $(69,72,74)$. Of the 3 randomized trials, 2 studies $(72,74)$ had similar patient characteristics. Manchikanti et al (74) also reported the proportion of patients included with a history of previous surgery, which ranged from $64 \%$ to $72 \%$ in all intervention groups. Patients in all 3 studies failed multiple conservative modalities of treatments including fluoroscopically directed epidural steroid injections. The study by Veihelmann et al (69) evaluated patients with a history of chronic low back pain and sciatica. Inclusion criteria were radicular pain with a corresponding nerve root with compressing substrate found on magnetic resonance imaging or computed tomography scans. Prior to randomization, all patients received physiotherapy, local injections, and analgesics. Local injections were not defined. All patients were evaluated for radicular pain by an independent neurologist. Exclusion factors were paralysis, spinal canal stenosis, rheumatologic disease, and malignancy. They did not identify which of these patients had post laminectomy syndrome. However, post laminectomy syndrome or epidural fibrosis were not exclusion criteria, and thus, it is believed that some of the patients probably included post laminectomy syndrome or epidural fibrosis patients.

Heavner et al (72) compared various types of solutions used after mechanical adhesiolysis; Group A received a combination of hyaluronidase and hypertonic saline; Group B, hypertonic saline solution; Group C, isotonic saline solution; and Group D, hyaluronidase and isotonic saline solution.

Manchikanti et al (74) divided 75 patients randomly into 3 groups, with Group I consisting of a control group without adhesiolysis, with injection of local anesthetic, steroid, and normal saline; Group II consisting of patients undergoing adhesiolysis, with injection of local anesthetic, steroid, and normal saline; and Group III consisting of patients undergoing adhesiolysis, with an injection of $10 \%$ sodium chloride solution, in addition to local anesthetic and steroid.

Heavner et al (72) evaluated a 3-day procedure where the catheter was inserted on the first day and the drugs were injected on the second and third day, whereas Manchikanti et al $(74,75)$ evaluated one-day 
Table 7. Results of observational studies of percutaneous adhesiolysis and hypertonic saline neurolysis.

\begin{tabular}{|c|c|c|c|c|c|}
\hline $\begin{array}{l}\text { Study/ } \\
\text { Methods }\end{array}$ & Participants & Intervention(s) & Outcome(s) & Result(s) & $\begin{array}{l}\text { Conclusion(s) } \\
\text { Short-term } \\
\text { relief } \leq 6 \mathrm{mos} \\
\text { Long-term } \\
\text { relief }>6 \mathrm{mos} \\
\end{array}$ \\
\hline $\begin{array}{l}\text { Manchikanti et } \\
\text { al (75) }\end{array}$ & $\begin{array}{l}45 \text { patients were } \\
\text { evaluated. } \\
15 \text { patients in Group } \\
\text { I were treated } \\
\text { conservatively. } \\
30 \text { patients in Group II } \\
\text { were treated with percu- } \\
\text { taneous epidural adhe- } \\
\text { siolysis and hypertonic } \\
\text { saline neurolysis. }\end{array}$ & $\begin{array}{l}\text { Experimental group: } \\
\text { adhesiolysis, hyper- } \\
\text { tonic saline neurolysis, } \\
\text { and epidural steroid } \\
\text { injection, one or more } \\
\text { occasions. } \\
\text { Control group: } \\
\text { physical therapy } \\
\text { exercise program and } \\
\text { medication. }\end{array}$ & $\begin{array}{l}\text { Timing: } 1 \text { month, } 3 \\
\text { months, } 6 \text { months, } \\
1 \text { year. } \\
\text { Outcome measures: } \\
\text { Pain relief, functional } \\
\text { status, psychological } \\
\text { status, employment } \\
\text { status. }\end{array}$ & $\begin{array}{l}\text { Experimental group } \\
\text { showed improvement } \\
\text { with pain relief in } 97 \% \\
\text { at } 3 \text { months, } 93 \% \text { at } 6 \\
\text { months, and } 47 \% \text { of } \\
\text { the patients at } 1 \text { year. } \\
\text { Generalized anxiety } \\
\text { disorder, somatization } \\
\text { disorder, average pain, } \\
\text { and functional status } \\
\text { improved significantly } \\
\text { in Group II. }\end{array}$ & $\begin{array}{l}\text { Positive short- } \\
\text { and long-term } \\
\text { relief. }\end{array}$ \\
\hline $\begin{array}{l}\text { Manchikanti et } \\
\text { al (77) }\end{array}$ & $\begin{array}{l}60 \text { post lumbar } \\
\text { laminectomy patients } \\
\text { were included after } \\
\text { failure of conservative } \\
\text { management. }\end{array}$ & $\begin{array}{l}\text { Adhesiolysis, hyper- } \\
\text { tonic saline neuroly- } \\
\text { sis, and injection of } \\
\text { steroid. }\end{array}$ & $\begin{array}{l}\text { Timing: } \\
3 \text { months, } 6 \text { months, } \\
12 \text { months } \\
\text { Outcome measures: } \\
\text { Pain relief. }\end{array}$ & $\begin{array}{l}\text { With multiple injec- } \\
\text { tions, initial relief was } \\
\text { seen in } 100 \% \text { of the } \\
\text { patients, however it } \\
\text { declined to } 90 \% \text { at } \\
3 \text { months, } 72 \% \text { at } 6 \\
\text { months, and } 52 \% \text { at } \\
1 \text { year. }\end{array}$ & $\begin{array}{l}\text { Positive short- } \\
\text { and long-term } \\
\text { relief. }\end{array}$ \\
\hline $\begin{array}{l}\text { Manchikanti et } \\
\text { al (76) }\end{array}$ & $\begin{array}{l}\text { A retrospective random- } \\
\text { ized evaluation of the } \\
\text { effectiveness of one-day } \\
\text { adhesiolysis and hyper- } \\
\text { tonic saline neurolysis in } \\
129 \text { patients. }\end{array}$ & $\begin{array}{l}\text { Adhesiolysis, hyper- } \\
\text { tonic saline neuroly- } \\
\text { sis, and injection of } \\
\text { steroid. }\end{array}$ & $\begin{array}{l}\text { Timing: } 4 \text { weeks, } 3 \\
\text { months, } 6 \text { months, } 12 \\
\text { months. } \\
\text { Outcome measures: } \\
\text { pain relief. }\end{array}$ & $\begin{array}{l}\text { Initial relief was } \\
\text { reported in } 79 \% \text { of the } \\
\text { patients with } 68 \% \text { of } \\
\text { the patients reporting } \\
\text { relief at } 3 \text { months, } \\
36 \% \text { at } 6 \text { months, and } \\
13 \% \text { at } 12 \text { months } \\
\text { with one injection. }\end{array}$ & $\begin{array}{l}\text { Positive short- } \\
\text { term and negative } \\
\text { long-term relief. }\end{array}$ \\
\hline $\begin{array}{l}\text { Gerdesmeyer et } \\
\text { al (71) }\end{array}$ & $\begin{array}{l}61 \text { patients with lumbar } \\
\text { radiculopathy treated } \\
\text { with percutaneous } \\
\text { adhesiolysis. }\end{array}$ & $\begin{array}{l}\text { All patients under- } \\
\text { went percutaneous ad- } \\
\text { hesiolysis "according } \\
\text { to Racz's technique"; } \\
\text { unclear whether one } \\
\text { day or } 3 \text { day protocol. }\end{array}$ & $\begin{array}{l}\text { Evaluation at } 3 \text { and } 6 \\
\text { months. } \\
\text { Outcome measures: } \\
\text { subjective pain scores } \\
\text { (McNab score). }\end{array}$ & $\begin{array}{l}\text { "Subjective pain } \\
\text { perception clearly } \\
\text { improved after } 3 \text { as } \\
\text { well as } 6 \text { months." }\end{array}$ & $\begin{array}{l}\text { Positive short- } \\
\text { term and long- } \\
\text { term relief. }\end{array}$ \\
\hline
\end{tabular}

adhesiolysis. Veihelmann et al (69) and Gerdesmeyer et al $(70,71)$ used a 3 -day protocol in all 3 studies. They also used hyaluronidase as part of the treatment protocol.

The outcome parameters by Heavner et al (72) included the short-form McGill Pain Questionnaire and Visual Analog Scale for back pain and leg pain. Manchikanti et al (74) utilized VAS pain scale, Oswestry Disability Index 2.0, work status, opioid intake, range of motion measurement, and psychological evaluation by Pain Patient Profile (P-3).

Outcome measures included in the third randomized clinical trial (76) were significant pain relief (> $50 \%)$, cumulative pain relief, physical health, mental health, functional status, narcotic intake, psychologi- cal status, and return to employment. Veihelmann et al (69) used Visual Analogue Scale scores for back pain and leg pain, Oswestry Disability Score, Gerbershagen Score, and a quantified score for the use of analgesics. They also used a blinded observer.

\section{Effectiveness}

Of the 3 randomized trials evaluating percutaneous adhesiolysis, all showed positive results for shortand long-term relief $(69,72,74)$. Of the 4 observational studies, 3 studies showed positive results for both short- and long-term improvement $(71,75,77)$, whereas one study (76) was positive for short-term and negative for long-term relief. 
Percutaneous Adhesiolysis and Management of Chronic Low Back Pain

Table 8. Results of published studies effectiveness of percutaneous lysis of lumbar epidural adhesions.

\begin{tabular}{|c|c|c|c|c|c|c|c|c|}
\hline \multirow[b]{2}{*}{ Study } & \multirow[b]{2}{*}{$\begin{array}{c}\text { Study } \\
\text { Characteristics }\end{array}$} & \multirow[b]{2}{*}{ Participants } & \multicolumn{4}{|c|}{ Pain Relief } & \multicolumn{2}{|c|}{ Results } \\
\hline & & & $\leq \mathbf{3}$ mos. & 3 mos. & 6 mos. & 12 mos. & $\begin{array}{l}\text { Short- } \\
\text { term } \leq \\
6 \text { mos. }\end{array}$ & $\begin{array}{c}\text { Long- } \\
\operatorname{term}>6 \\
\text { mos. }\end{array}$ \\
\hline Manchikanti et al 2004 (74) & RA, DB & $\begin{array}{l}\mathrm{G} 1=25 \\
\mathrm{G} 2=25 \\
\mathrm{G} 3=25\end{array}$ & $\begin{array}{l}\mathrm{G} 1=33 \% \\
\mathrm{G} 2=64 \% \\
\mathrm{G} 2=72 \%\end{array}$ & $\begin{aligned} \mathrm{G} 1 & =0 \% \\
\mathrm{G} 2 & =64 \% \\
\mathrm{G} 3 & =72 \%\end{aligned}$ & $\begin{aligned} \mathrm{G} 1 & =0 \% \\
\mathrm{G} 2 & =60 \% \\
\mathrm{G} 3 & =72 \%\end{aligned}$ & $\begin{aligned} \mathrm{G} 1 & =0 \% \\
\mathrm{G} 2 & =60 \% \\
\mathrm{G} 3 & =72 \%\end{aligned}$ & $\mathrm{P}$ & $\mathrm{P}$ \\
\hline Heavner et al 1999 (72) & $\mathrm{RA}, \mathrm{DB}$ & 59 & $83 \%$ & $49 \%$ & $43 \%$ & $49 \%$ & $\mathrm{P}$ & $\mathrm{P}$ \\
\hline Veihelmann et al 2006 (69) & RA & 99 & SI & SI & SI & SI & $\mathrm{P}$ & $\mathrm{P}$ \\
\hline Manchikanti et al 2001(75) & $\mathrm{O}$ & $\begin{aligned} \mathrm{G} 1 & =15 \\
\mathrm{G} 2 & =30\end{aligned}$ & & $97 \%$ & $93 \%$ & $47 \%$ & $\mathrm{P}$ & $\mathrm{P}$ \\
\hline Manchikanti et al 1999(77) & $\mathrm{O}$ & 60 & $100 \%$ & $90 \%$ & $72 \%$ & $52 \%$ & $\mathrm{P}$ & $\mathrm{P}$ \\
\hline Manchikanti et al 1999(76) & $\mathrm{O}$ & 129 & $79 \%$ & $68 \%$ & $36 \%$ & $13 \%$ & $\mathrm{P}$ & $\mathrm{N}$ \\
\hline Gerdesmeyer et al 2005 (71) & $\mathrm{O}$ & 61 & SI & SI & SI & SI & $\mathrm{P}$ & $\mathrm{P}$ \\
\hline
\end{tabular}

$\mathrm{RA}=$ randomized $\mathrm{DB}=$ double blind $\mathrm{O}=$ observational $\mathrm{G}=$ group $; \mathrm{SI}=$ significant improvement $\mathrm{P}=$ positive; $\mathrm{N}=$ negative

Table 8 illustrates results of effectiveness of percutaneous adhesiolysis.

\section{Level of Evidence}

The indicated level of evidence is I or II-1 for shortand long-term relief for percutaneous adhesiolysis in post lumbar laminectomy syndrome.

\section{Recommendations}

Based on Guyatt et al (101), grading strength of recommendations and quality of evidence in clinical guidelines, the recommendation is strong, with $1 \mathrm{~B}$ or 1C for percutaneous adhesiolysis in post lumbar laminectomy syndrome.

\section{Complications}

The most commonly reported complications of percutaneous adhesiolysis were dural puncture, catheter shearing, and infection (24-28,69-77,108-114). Other potential complications include intravascular injection; vascular injury; cerebral vascular or pulmonary embolus; reaction to the steroids; hypertonic saline, or hyaluronidase, and administration of high volumes of fluids potentially resulting in excessive epidural hydrostatic pressures; death; and brain damage $(24-28,113)$.
Other side effects are related to the administration of steroids and are generally attributed to the chemistry or pharmacology of the steroids (115-118). However, therapeutic doses of epidural steroids in appropriate dosing did not result in complications (119).

\section{Discussion}

This systematic review of the effectiveness of percutaneous adhesiolysis in post lumbar surgery syndrome indicated Level I or II-1 evidence for short- and long-term relief based on USPSTF criteria and strong/ 1B or 1C recommendation based on Guyatt et al's (101) criteria. The evidence was derived from randomized control trials and observational studies. The results of this systematic review are similar to previous systematic reviews and guidelines $(24,26,27,102)$. However, in this evaluation we focused on post laminectomy syndrome only as there is a paucity of evidence for other conditions. Further, we have also expanded the definition of short-term relief to 6 months or less, whereas long-term relief is defined as longer than 6 months - a robust measure. Even then, evidence for percutaneous adhesiolysis for both and short- and longterm continues to be Level I or II-1, yielding a strong recommendation. 
In this systematic review, we utilized 3 randomized trials $(69,72,74)$ and $4(71,75-77)$ observational studies meeting the inclusion criteria. This systematic review has shown that percutaneous adhesiolysis is an effective treatment, it is superior to epidural steroid injections, the addition of hypertonic sodium chloride solution and hyaluronidase may or may not improve the outcomes, and it is a safe procedure when performed appropriately. Of all the 3 randomized trials $(69,72,74)$ and 4 observational studies $(71,75-77)$ evaluated, the effectiveness of percutaneous adhesiolysis was demonstrated both with one-day and 3-day procedures. Two randomized trials $(69,72)$ evaluated adhesiolysis with a 3-day protocol, whereas one randomized trial (74), and 3 observational studies evaluated percutaneous adhesiolysis on one-day basis (75-77). The study by Veihelmann et al (69) was not double blind, whereas Heavner et al (72) and Manchikanti et al (74) used a non-inferiority or equivalence control design $(95,96$, 120-122).

This review showed percutaneous adhesiolysis is clearly superior to fluoroscopically directed epidural steroid injections. Further, this review also demonstrated modalities of an effective management of chronic, refractory low back and lower extremity pain, specifically secondary to post lumbar laminectomy syndrome. This systematic review with stringent inclusion and exclusion as well as methodological quality criteria, demonstrated that the technique of adhesiolysis overcomes the obstacle of being able to get various medications to a lesion specific site by placing the tip of a soft spring catheter within the scar, and thereby opening the perineural space. Thus, the steroid and other solutions reach the appropriate site and provide anti-inflammatory effect and neural blockade.

Despite multiple publications, discussions continue with regards to long-term effectiveness of percutaneous adhesiolysis. This systematic review failed to show any significant evidence for hyaluronidase. Hyaluronidase is an enzyme additive used for adhesiolysis. Only a limited number of studies described the influence of drugs on hyaluronidase activity. In an experimental evaluation of hyaluronidase activity in combination with specific drugs applied in clinical techniques of interventional pain management, Schulze et al (123) showed that drugs affecting the activity of hyaluronidase with decreased effectiveness for iodinated contrast media and $10 \%$ sodium chloride solution; whereas, corticosteroids and isotonic sodium chloride solution, $0.9 \%$, increased the activity with no effect with combination of local anesthetics. Thus, it would be extremely difficult to evaluate the effect of hyaluronidase since multiple drugs are utilized in adhesiolysis.

The methodological quality and number of patients included in the studies may be criticized in the randomized trials of percutaneous adhesiolysis. Heavner et al (72) evaluated 59 patients with chronic intractable low back pain. All the patients failed conservative management, along with fluoroscopically directed epidural steroid injections. Consequently these authors studied the effect of isotonic saline, hypertonic saline plus hyaluronidase, and finally isotonic saline plus hyaluronidase. The patients functioned as their own controls for the purposes of adhesiolysis. The authors measured various outcomes at 4 weeks, 3 months, 6 months, and 12 months. Their outcome measures included pain relief by visual analog scale. From a total of 83 patients recruited, 24 patients were removed from the study before the injection series was completed, leaving 59 patients that completed the study. The authors did not perform an intentionto-treat analysis. The results showed $49 \%$ of the patients with significant improvement at 3 months, $43 \%$ at 6 months, and $49 \%$ at 12 months. However the study has been misinterpreted in the past due to a lack of differences between various groups (103). In this study (72), all the patients prior to being enrolled in the randomized, double-blind study failed to respond to many types of conservative modalities of treatment including fluoroscopically directed epidural steroid injections. Thus, this study provided evidence for the effectiveness of adhesiolysis, but not for injection of hypertonic saline or hyaluronidase.

The second randomized trial of percutaneous adhesiolysis by Manchikanti et al (74) evaluated one-day lumbar epidural adhesiolysis and hypertonic saline neurolysis in the treatment of chronic low back pain with a randomized, double-blind design. These authors studied a total of 75 patients with 25 patients in each group using 3 types of interventions. Group I served as controls undergoing catheterization without adhesiolysis, followed by injection of local anesthetic, normal saline, and steroid. Group II consisted of catheterization and adhesiolysis followed by injection of local anesthetic, normal saline, and steroid. Group III consisted of adhesiolysis followed by injection of local anesthetic, hypertonic saline, and steroid. These authors also incorporated statistical analysis which included intent-to-treat analysis. They included exten- 
sive outcome measures with visual analog pain scores, Oswestry Disability Index, work status, opioid intake, range of motion measurement, and psychological status. They defined significant pain relief as average relief of $50 \%$ or greater. Their results showed that significant improvement was seen in patients in Group II and Group III at 3 months, 6 months, and 12 months, compared to baseline measurements, as well as compared to Group I without adhesiolysis. In this study, $72 \%$ of the patients in Group III with adhesiolysis and hypertonic saline neurolysis improved, compared to $60 \%$ of the patients in Group II with adhesiolysis only showed significant improvement at 12-month followup compared to $0 \%$ in Group I, which was without adhesiolysis, but did have a steroid injection. These authors also showed that the average number of treatments for one year were 2.76 in Group II and 2.16 in Group III. Duration of significant relief with the first procedure was $2.8 \pm 1.9$ months in Group II and $3.8 \pm$ 3.37 months in Group III. Consequently, the authors of this review concur with the authors of the study which concluded that percutaneous adhesiolysis, with or without hypertonic saline neurolysis, is an effective treatment for chronic low back pain.

The third study also used by the American College of Occupational and Environmental Medicine (ACOEM) assessment was of Veihelmann et al (69). The study is described as a moderate quality randomized controlled trial looked at 99 patients with chronic low back pain and sciatica based on disc protrusion/prolapse or failed back surgery, with 52 patients receiving physiotherapy compared to 47 patients undergoing epidural neuroplasty on a short-term basis as well as at 12 months of followup. The diagnosis of sciatica was based on radicular pain and a positive MRI, with VAS scores suggesting slightly worse leg pain than low back pain (124). The authors of this manuscript (69) concluded that taking into account that the results of discectomy are not necessarily superior to conservative treatment, the data shows, for the first time, that for patients with radicular pain due to disc protrusion and herniation or epidural fibrosis, epidural neuroplasty seems to be an effective safe alternative treatment (124). The authors (69) also concluded that at least 3 months after neuroplasty, it is superior in comparison to conservative treatment with physiotherapy. Nevertheless, they suggested that further prospective randomized double-blinded studies should be performed to prove the effectiveness of epidural neuroplasty in comparison to placebo and in comparison to open discectomy procedures (69). Consequently, due to a poor evaluation process of ACOEM guidelines, reassessment of these guidelines was carried out (82). The quality of the guidelines was assessed (125) and the potential implications were described (126). In addition, multiple studies have been performed utilizing equivalence or non-inferiority design $(32-35,72,74)$. Thus in appropriate evidence synthesis, all types of evidence must be utilized (130-134).

The limitations of this systematic review include the lack of new evidence since the previous systematic reviews. However, this systematic review continued to show significant evidence with studies meeting methodologic quality assessment. This systematic review is different from others in that short-term relief was defined as at least 6 months and long-term relief was defined as longer than 6 months. Combining assessment of clinical relevance and methodologic quality assessment, this review provides significant evidence of modest relief from percutaneous adhesiolysis in appropriately selected patients with post lumbar surgery syndrome with persistent pain.

\section{Conclusion}

This systematic review of the effectiveness of percutaneous adhesiolysis in the management of chronic low back pain in post lumbar surgery syndrome indicated Level I to II-1 evidence, based on 3 randomized trials, with a strong recommendation.

\section{Acknowledgments}

The authors wish to thank the editorial board of Pain Physician, for review and criticism in improving the manuscript; Sekar Edem for assistance in search of literature; and Tonie M. Hatton and Diane E. Neihoff, transcriptionists (Pain Management Center of Paducah), for their assistance in the preparation of this manuscript. 


\section{References}

1. Cummins J, Lurie JD, Tosteson TD, Hanscom B, Abdu WA, Birkmeyer NJ, Herkowitz $\mathrm{H}$, Weinstein J. Descriptive epidemiology and prior healthcare utilization of patients in the Spine Patient Outcomes Research Trial's (SPORT) three observational cohorts: Disc herniation, spinal stenosis, and degenerative spondylolisthesis. Spine 2006; 31:806-814.

2. Cherkin DC, Deyo RA, Loeser JD, Bush T, Waddell G. An international comparison of back surgery rates. Spine 1994; 19:1201-1206.

3. Schofferman J, Reynolds J, Herzog R, Covington $E$, Dreyfuss $P$, O'Neill $C$. Failed back surgery: Etiology and diagnostic evaluation. Spine / 2003; 3:400403.

4. Waguespack A, Schofferman J, Slosar $\mathrm{P}$, Reynolds J. Etiology of long-term failures of lumbar spine surgery. Pain Med 2002; 3:18-22.

5. Waddell G, Kummel EG, Lotto WN, Graham JD, Hall H, McCulloch JA. Failed lumbar disc surgery and repeat surgery following industrial injury. I Bone Joint Surg Am 1979; 61:201-207.

6. Weinstein JN, Tosteson TD, Lurie JD, Tosteson AN, Blood E, Hanscom B, Herkowitz H, Cammisa F, Albert T, Boden SD, Hilibrand A, Goldberg H, Berven $\mathrm{S}$, An H; SPORT Investigators. Surgical versus nonsurgical therapy for lumbar spinal stenosis. N Engl J Med 2008; 358:794-810.

7. Deyo RA, Ciol MA, Cherkin DC, Loeser JD, Bigos SJ. Lumbar spinal fusion: A cohort study of complications, reoperations, and resource use in the Medicare population. Spine 1993; 18:1463-1470.

8. Deyo RA, Gray DT, Kreuter W, Mirza S, Martin BI. United States trends in lumbar fusion surgery for degenerative conditions. Spine 2005; 30:1441-1445.

9. Ross JS, Robertson JT, Frederickson RC, Petrie JL, Obuchowski N, Modic MT, de Tribolet N. Association between peridural scar and recurrent radicular pain after lumbar discectomy: Magnetic resonance evaluation. Neurosurgery 1996; 38:855-863.

10. Fritsch EW, Heisel J, Rupp S. The failed back surgery syndrome. Reasons, intraoperative findings, and long-term results: A report of 182 operative treatments. Spine 1996; 21:626-633.

11. Osterman H, Sund R, Seitsalo S, Keskimaki I. Risk of multiple reoperations after lumbar discectomy: A population- based study. Spine 2003; 28:621-627.

12. Bono CM, Lee CK. Critical analysis of trends in fusion for degenerative disc disease over the past 20 years: Influence of technique of fusion rate and clinical outcome. Spine 2004; 29:455463.

13. Law JD, Lehman RAW, Kirsch WM. Reoperation after lumbar intervertebral disc surgery. J Neurosurg 1978; 48:259-263.

14. Mirza SK, Deyo RA. Systematic review of randomized trials comparing lumbar fusion surgery to nonoperative care for treatment of chronic back pain. Spine 2007; 32:816-823.

15. Lieberman IH. Disc bulge bubble: Spine economics 101. Spine J 2004; 4:609613.

16. Deyo RA, Nachemson A, Mirza SK. Spinal fusion surgery - The case for restraint. N Engl J Med 2004; 350:722726.

17. Deyo RA, Mirza SK. Trends and variations in the use of spine surgery. Clin Orthop Relat Res 2006; 443:139-146.

18. ECRI Health Technology Assessment Group. Treatment of degenerative lumbar spinal stenosis. Evid Rep Technol Assess (Summ) 2001; 32:1-5.

19. Weinstein JN, Lurie JD, Olson PR, Bronner KK, Fisher ES. United States' trends and regional variations in lumbar spine surgery: 1992 - 2003. Spine 2006; 31:2707-2714

20. Brox Jl, Sørensen R, Friis A, Nygaard $\varnothing$, Indahl A, Keller A, Ingebrigtsen T, Eriksen HR, Holm I, Koller AK, Riise R, Reikerås $\mathrm{O}$. Randomized clinical trial of lumbar instrumented fusion and cognitive intervention and exercises in patients with chronic low back pain and disc degeneration. Spine 2003; 28:1913-1921.

21. Ciol MA, Deyo RA, Howell E, Kreif S. An assessment of surgery for spinal stenosis: Time trends, geographic variations, complications, and reoperations. / $\mathrm{Am}$ Geriatr Soc 1996; 44:285-290.

22. Harkness EF, Macfarlane GJ, Silman AJ, McBeth J. Is musculoskeletal pain more common now than 40 years ago?: Two population-based cross-sectional studies. Rheumatology (Oxford) 2005; 44:890-895.

23. Freburger JK, Holmes GM, Agans RP Jackman AM, Darter JD, Wallace AS, Castel LD, Kalsbeek WD, Carey TS. The rising prevalence of chronic low back pain. Arch Intern Med 2009; 169:251-258.
24. Trescot AM, Chopra P, Abdi S, Datta S, Schultz DM. Systematic review of effectiveness and complications of adhesiolysis in the management of chronic spinal pain: An update. Pain Physician 2007; 10:129-146.

25. Manchikanti L, Bakhit CE. Percutaneous lysis of epidural adhesions. Pain Physician 2000; 3:46-64.

26. Boswell MV, Trescot AM, Datta S, Schultz DM, Hansen HC, Abdi S, Sehgal N, Shah RV, Singh V, Benyamin RM, Patel VB, Buenaventura RM, Colson JD, Cordner HJ, Epter RS, Jasper JF, Dunbar EE, Atluri SL, Bowman RC, Deer TR, Swicegood JR, Staats PS, Smith HS, Burton AW, Kloth DS, Giordano J, Manchikanti L. Interventional techniques: Evidencebased practice guidelines in the management of chronic spinal pain. Pain Physician 2007; 10:7-111.

27. Chopra P, Smith HS, Deer TR, Bowman $\mathrm{RC}$. Role of adhesiolysis in the management of chronic spinal pain: A systemic review of effectiveness and complications. Pain Physician 2005; 8:87-100.

28. Manchikanti L, Singh V. Epidural lysis of adhesions and myeloscopy. Curr Pain Headache Rep 2002; 6:427-435.

29. Manchikanti L, Singh V. Failed back surgery: Etiology and diagnostic evaluation. Spine J 2004; 4:486-488.

30. Manchikanti L, Bakhit CE, Pampati V. Role of epidurography in caudal neuroplasty. Pain Digest 1998; 8:277-281.

31. Manchikanti L, Manchukonda R, Pampati V, Damron KS, McManus CD. Prevalence of facet joint pain in chronic low back pain in postsurgical patients by controlled comparative local anesthetic blocks. Arch Phys Med Rehabil 2007; 88:449-455.

32. Manchikanti L, Singh V, Cash KA, Pampati V, Datta S. Preliminary results of randomized, equivalence trial of fluoroscopic caudal epidural injections in managing chronic low back pain: Part 3. Post surgery syndrome. Pain Physician 2008; 11:817-831.

33. Manchikanti L, Cash KA, McManus CD, Pampati V, Abdi S. Preliminary results of randomized, equivalence trial of fluoroscopic caudal epidural injections in managing chronic low back pain: Part 4. Spinal stenosis. Pain Physician 2008; 11:833-848.

34. Manchikanti L, Cash KA, McManus CD, Pampati V, Smith HS. Preliminary re- 
sults of randomized, equivalence trial of fluoroscopic caudal epidural injections in managing chronic low back pain: Part 1. Discogenic pain without disc herniation or radiculitis. Pain Physician 2008; 11:785-800.

35. Manchikanti L, Singh V, Cash KA, Pampati V, Damron KS, Boswell MV. Preliminary results of randomized, equivalence trial of fluoroscopic caudal epidural injections in managing chronic low back pain: Part 2. Disc herniation and radiculitis. Pain Physician 2008; 11:801-815.

36. Conn A, Buenaventura RM, Datta S, Abdi S, Diwan S. Systematic review of caudal epidural injections in the management of chronic low back pain. Pain Physician 2009; 12:109-135.

37. Boswell MV, Hansen HC, Trescot AM, Hirsch JA. Epidural steroids in the management of chronic spinal pain and radiculopathy. Pain Physician 2003; 6:319-334

38. Abdi S, Datta $S$, Trescot AM, Schultz DM, Adlaka R, Atluri SL, Smith HS, Manchikanti L. Epidural steroids in the management of chronic spinal pain: A systematic review. Pain Physician 2007; 10:185-212.

39. Manchikanti L, Saini B, Singh V. Spinal endoscopy and lysis of epidural adhesions in the management of chronic low back pain. Pain Physician 2001; 4:240-265.

40. Hayek SM, Helm S, Benyamin RM, Singh V, Bryce DA, Smith HS. Effectiveness of spinal endoscopic adhesiolysis in post lumbar surgery syndrome: A systematic review. Pain Physician 2009; 12:419-435.

41. Hansen HC, McKenzie-Brown AM, Cohen $S P$, Swicegood JR, Colson JD, Manchikanti L. Sacroiliac joint interventions: A systematic review. Pain Physician 2007; 10:165-184.

42. Rupert MP, Lee M, Manchikanti L, Datta $S$, Cohen SP. Evaluation of sacroiliac joint interventions: A systematic appraisal of the literature. Pain Physician 2009; 12:399-418.

43. Datta S, Lee M, Falco FJE, Bryce DA, Hayek SM. Systematic assessment of diagnostic accuracy and therapeutic utility of lumbar facet joint interventions. Pain Physician 2009; 12:437460.

44. Boswell MV, Colson JD, Sehgal N, Dunbar EE, Epter R. A systematic review of therapeutic facet joint interventions in chronic spinal pain. Pain Physician 2007; 10:229-253.

45. McKenzie-Brown AM, Shah RV, Sehgal $\mathrm{N}$, Everett CR. A systematic review of sacroiliac joint interventions. Pain Phy sician 2005; 8:115-125.

46. Boswell MV, Colson JD, Spillane WF. Therapeutic facet joint interventions in chronic spinal pain: A systematic review of effectiveness and complications. Pain Physician 2005; 8:101-114.

47. Maliszewski $M$, Tymowski $M$, Lelek $P_{,}$ Bierzynska-Macyszyn G, Majchrzak H. An attempt to use Gore-Tex surgical membrane in lumbar disc surgery. Neurol Neurochir Pol 2004; 38:271-277.

48. Kayaoglu CR, Calikoglu C, Binler S. Reoperation after lumbar disc surgery: Results in 85 cases. J Int Med Res 2003; 31:318-323.

49. Hoyland JA, Freemont AJ, Jayson M. Intervertebral foramen venous obstruction. A cause of periradicular fibrosis? Spine 1989; 14:558-568.

50. Rydevik BL. The effects of compression on the physiology of nerve roots. J Manipulative Physiol Ther 1992; 15:62-66.

51. Songer M, Ghosh L, Spencer D. Effects of sodium hyaluronate on peridural fibrosis after lumbar laminectomy and discectomy. Spine 1990; 15:550-554.

52. North RB, Campbell JN, James CS, Conover-Walker MK, Wang H, Piantadosi S, Rybock JD, Long DM. Failed back surgery syndrome: 5-year followup in 102 patients undergoing repeated operation. Neurosurgery 1991; 28:685690.

53. Massie JB, Huang B, Malkmus $S$, Yaksh TL, Kim CW, Garfin SR, Akeson WH. A preclinical post laminectomy rat model mimics the human post laminectomy syndrome. I Neurosci Methods 2004; 137:283-289.

54. Massie JB, Schimizzi AL, Huang B, Kim CW, Garfin SR, Akeson WH. Topical high molecular weight hyaluronan reduces radicular pain post laminectomy in a rat model. Spine J 2005; 5:494-502.

55. Harrington JF, Messier AA, Hoffman $L$, Yu E, Dykhuizen M, Barker K. Physiological and behavioral evidence for focal nociception induced by epidural glutamate infusion in rats. Spine 2005 ; 30:606-612.

56. Haq I, Cruz-Almeida Y, Siqueira EB, Norenberg $M$, Green BA, Levi AD. Postoperative fibrosis after surgical treatment of the porcine spinal cord: A compari- son of dural substitutes. Invited submission from the Joint Section Meeting on Disorders of the Spine and Peripheral Nerves, March 2004. J Neurosurg Spine 2005; 2:50-54.

57. Buvanendran A, Kroin JS, Kerns JM, Nagalla SN, Tuman KJ. Characterization of a new animal model for evaluation of persistent postthoracotomy pain. Anesth Analg 2004; 99:1453-1460.

58. Kim KD, Wang JC, Robertson DP, Brodke DS, BenDebba M, Block KM, diZerega GS. Reduction of leg pain and lower-extremity weakness for 1 year with Oxiplex/SP gel following laminectomy, laminotomy, and discectomy. Neurosurg Focus 2004; 17:ECP1.

59. Gibson JN, Waddell G. Surgery for degenerative lumbar spondylosis. Cochrane Database Syst Rev 2005; 4: CD001352.

60. Huntoon MC, Burgher AH. Back to the future: The end of the steroid century? Pain Physician 2008; 11:713-716.

61. Manchikanti L, Giordano J. Physician payment 2008 for interventionalists: Current state of health care policy. Pain Physician 2007; 10:607-626.

62. Manchikanti L, Hirsch JA. Issues in Health Care: Interventional pain management at the crossroads. Health Policy Update. Pain Physician 2007; 10:261-284.

63. Manchikanti L. Health care reform in the United States: Radical surgery needed now more than ever. Pain Physician 2008; 11:13-42.

64. Manchikanti L, Singh V, Pampati V, Smith HS, Hirsch J. Analysis of growth in interventional techniques in managing chronic pain in Medicare population: A 10-year evaluation from 1997 to 2006. Pain Physician 2009; 12:9-34.

65. Friedly J, Chan L, Deyo R. Increases in lumbosacral injections in the Medicare population: 1994 to 2001. Spine 2007; 32:1754-1760

66. Friedly J, Chan L, Deyo R. Geographic variation in epidural steroid injection use in Medicare patients. I Bone Joint Surg Am 2008; 90:1730-1737.

67. Revel M, Auleley GR, Alaoui S, Nguyen M, Duruoz T, Eck-Michaud S, Roux C, Amor B. Forceful epidural injections for the treatment of lumbosciatic pain with post-operative lumbar spinal fibrosis. Rev Rhum Engl Ed 1996; 63:270-277.

68. Hesla PE, Breivik H. Epidural analgesia and epidural steroid injection for treat- 
ment of chronic low back pain and sciatica. Tidsskr Nor Laegeforen 1979; 99:936-939.

69. Veihelmann A, Devens $C$, Trouiller $H$, Birkenmaier C, Gerdesmeyer L, Refior HJ. Epidural neuroplasty versus physiotherapy to relieve pain in patients with sciatica: A prospective randomized blinded clinical trial. J Orthop Science 2006; 11:365-369.

70. Gerdesmeyer L, Rechl H, Wagenpfeil S, Ulmer M, Lampe R, Wagner K. Minimally invasive epidural neurolysis in chronic radiculopathy. A prospective controlled study to prove effectiveness. Der Orhopade 2003; 32:869-876.

71. Gerdesmeyer $L$, Lampe $R$, Veihelmann A, Burgkart R, Gobel M, Gollwitzer H, Wagner K. Chronic radiculopathy. Use of minimally invasive percutaneous epidural neurolysis according to Racz. Der Schmerz 2005; 19:285-295.

72. Heavner JE, Racz GB, Raj P. Percutaneous epidural neuroplasty. Prospective evaluation of $0.9 \% \mathrm{NaCl}$ versus $10 \%$ $\mathrm{NaCl}$ with or without hyaluronidase. Reg Anesth Pain Med 1999; 24:202 207.

73. Racz GB, Heavner JE, Raj PP. Percutaneous epidural neuroplasty. Prospective one-year follow up. Pain Digest 1999; 9:97-102.

74. Manchikanti L, Rivera J, Pampati V, Damron KS, McManus CD, Brandon DE, Wilson SR. One day lumbar epidural adhesiolysis and hypertonic saline neurolysis in treatment of chronic low back pain: A randomized double blind trial. Pain Physician. 2004; 7:177-186.

75. Manchikanti L, Pampati V, Fellows B, Rivera JJ, Beyer CD, Damron KS. Role of one day epidural adhesiolysis in management of chronic low back pain: A randomized clinical trial. Pain Physician 2001; 4:153-166.

76. Manchikanti L, Pakanati R, Bakhit $\mathrm{CE}_{\text {, }}$ Pampati V. Role of adhesiolysis and hypertonic saline neurolysis in management of low back pain. Evaluation of modification of Racz protocol. Pain Digest 1999; 9:91-96.

77. Manchikanti L, Pampati V, Bakhit $\mathrm{CE}$, Pakanati RR. Non-endoscopic and endoscopic adhesiolysis in post lumbar laminectomy syndrome. A one-year outcome study and cost effective analysis. Pain Physician 1999; 2:52-58.

78. Shojania KG, Sampson M, Ansari MT, Ji J, Doucette S, Moher D. How quickly do systematic reviews go out of date?
A survival analysis. Ann Intern Med 2007; 147:224-233.

79. Koes BW, Scholten RJ, Mens JMA, Bouter LM. Efficacy of epidural steroid injections for low-back pain and sciatica: A systematic review of randomized clinical trials. Pain 1995; 63:279-288.

80. West S, King V, Carey T, Lohr K, McKoy N, Sutton S, Lux L. Systems to rate the strength of scientific evidence. Evidence Report/Technology Assessment No. 47 University of North Carolina: Agency for Healthcare Research and Quality. AHRQ Publication No. 02-E016; April 2002.

81. Nelemans PJ, Debie RA, DeVet HC, Sturmans $F$. Injection therapy for subacute and chronic benign low back pain. Spine 2001; 26:501-515.

82. Manchikanti L, Singh V, Derby R, Schultz DM, Benyamin RM, Prager JP, Hirsch $J A$. Reassessment of evidence synthesis of occupational medicine practice guidelines for interventional pain management. Pain Physician 2008; 11:393482

83. Atluri S, Datta S, Falco FJ, Lee M. Systematic review of diagnostic utility and therapeutic effectiveness of thoracic facet joint interventions. Pain Physician 2008; 11:611-629.

84. Falco FJE, Erhart S, Wargo BW, Bryce DA, Atluri S, Datta S, Hayek SM. Systematic review of diagnostic utility and therapeutic effectiveness of cervical facet joint interventions. Pain Physician 2009; 12:323-344.

85. Buenaventura RM, Datta $S$, Abdi $S$, Smith HS. Systematic review of therapeutic lumbar transforaminal epidural steroid injections. Pain Physician 2009; 12:233-251.

86. Helm S, Hayek S, Benyamin RM, Manchikanti L. Systematic review of the effectiveness of thermal annular procedures in treating discogenic low back pain. Pain Physician 2009; 12:207-232.

87. Parr AT, Diwan S, Abdi S. Lumbar interlaminar epidural injections in managing chronic low back and lower extremity pain: A systematic review. Pain Phy sician 2009; 12:163-188.

88. Benyamin RM, Singh V, Parr AT, Conn A, Diwan S, Abdi S. Systematic review of the effectiveness of cervical epidurals in the management of chronic neck pain. Pain Physician 2009; 12:137-157.

89. Frey ME, Manchikanti L, Benyamin RM, Schultz DM, Smith HS, Cohen SP. Spi- nal cord stimulation for patients with failed back surgery syndrome: A systematic review. Pain Physician 2009; 12:379-397

90. Patel VB, Manchikanti L, Singh V, Schultz DM, Hayek SM, Smith HS. Systematic review of intrathecal infusion systems for long-term management of chronic non-cancer pain. Pain Physician 2009; 12:345-360.

91. Staal JB, de Bie R, de Vet HC, Hildebrandt J, Nelemans P. Injection therapy for subacute and chronic low-back pain. Cochrane Database Syst Rev 2008; 3:CD001824.

92. van Tulder $M$, Furlan $A$, Bombardier C, Bouter L, Editorial Board of the Cochrane Collaboration Back Review Group. Updated method guidelines for systematic reviews in the Cochrane Collaboration Back Review Group. Spine 2003; 28:1290-1299.

93. Salaffi $F$, Stancati A, Silvestri CA, Ciapetti A, Grassi W. Minimal clinically important changes in chronic musculoskeletal pain intensity measured on a numerical rating scale. Eur J Pain 2004; 8:283-291.

94. Bombardier C. Outcome assessments in the evaluation of treatment of spinal disorders: Summary and general recommendations. Spine 2000; 25:31003103.

95. Manchikanti L, Boswell MV, Giordano J. Evidence-based interventional pain management: Principles, problems, potential and applications. Pain Physician 2007; 10:329-356.

96. Manchikanti L. Evidence-based medicine, systematic reviews, and guidelines in interventional pain management: Part 1: Introduction and general considerations. Pain Physician 2008; 11:161-186.

97. Manchikanti L, Hirsch JA, Smith HS. Evidence-based medicine, systematic reviews, and guidelines in interventional pain management: Part 2: Randomized controlled trials. Pain Physician 2008; 11:717-773.

98. Manchikanti L, Benyamin RM, Helm S, Hirsch JA. Evidence-based medicine, systematic reviews, and guidelines in interventional pain management: Part 3: Systematic reviews and meta-analysis of randomized trials. Pain Physician 2009; 12:35-72.

99. Manchikanti L, Singh V, Smith HS, Hirsch JA. Evidence-based medicine, systematic reviews, and guidelines in 
interventional pain management: Part 4: Observational studies. Pain Physician 2009; 12:73-108.

100. Berg AO, Allan JD. Introducing the third U.S. Preventive Services Task Force. Am J Prev Med 2001; 20:S3-S4.

101. Guyatt G, Gutterman D, Baumann MH, Addrizzo-Harris D, Hylek EM, Phillips B, Raskob G, Lewis SZ, Schünemann $\mathrm{H}$. Grading strength of recommendations and quality of evidence in clinical guidelines. Report from an American College of Chest Physicians Task Force. Chest 2006; 129:174-181.

102. Racz GB, Heavner JE, Trescot A. Percutaneous lysis of epidural adhesionsevidence for safety and efficacy. Pain Pract 2008; 8:277-286.

103. Belozer M, Wang G. Epidural adhesiolysis for the treatment of back pain. Health Technol Assess 2004; 5:1-19.

104. Manchikanti L, Pampati V, Rivera J, Fellows B, Beyer CD, Damron KS, Cash KA. Effectiveness of percutaneous adhesiolysis and hypertonic saline neurolysis in refractory spinal stenosis. Pain Physician 2001; 4:366-373.

105. Hammer M, Doleys D, Chung O. Transforaminal ventral epidural adhesiolysis. Pain Physician 2001; 4:273-279.

106. Devulder J, Bogaert L, Castille F, Moerman A, Rolly G. Relevance of epidurography and epidural adhesiolysis in chronic failed back surgery patients. Clin J Pain 1995; 11:147-150.

107. Girgin NK, Gurbet A, Turker G, Uckunkaya N, Sahin S. Lumbar epidural lysis: A cranio-caudal lateral intralaminar approach. Pain Clin 2005; 17:225-228.

108. Talu GK, Erdine S. Complications of epidural neuroplasty: A retrospective evaluation. Neuromodulation 2003; 6:237347.

109. Perkins WJ, Davis DH, Huntoon MA, Horlocker TT. A retained Racz catheter fragment after epidural neurolysis: implications during magnetic resonance imaging. Anesth Analg 2003; 96:17171719.

110. Wagner KJ, Sprenger T, Pecho C, Kochs $E F$, Tölle TR, Berthele A, Gerdesmeyer L. Risks and complications of epidural neurolysis - a review with case report. Anasthesiol Intensmed Notfallmed Schmerzther 2006; 41:213-222.

111. Akbas M, Karsli B. Caudal epidural neuroplasty. Agri 2005; 17:40-43.

112. Manchikanti L, Bakhit CE. Removal of a torn $\mathrm{RaCz}^{\circledast}$ catheter from lumbar epi- dural space. Reg Anesth 1997; 22:579581.

113. Manchikanti L, Heavner JE, Racz GB. Percutaneous lysis of lumbar epidural adhesions. In: Manchikanti L, Singh $\mathrm{V}$ (eds.) Interventional Techniques in Chronic Spinal Pain, ASIPP Publishing, Paducah, KY, 2007; pp 479-506.

114. Simpoulos TT, Kraemer JJ, Glazer $P$, Bajwa ZH. Vertebral Osteomyelitis: A Potentially Catastrophic Outcome after Lumbar Epidural Steroid Injection. Pain Physician 2008; 11:693-697.

115. Manchikanti L. Role of neuraxial steroids in interventional pain management. Pain Physician 2002; 5:182-199.

116. Lucas JS, Ducker TB, Perot PL. Adverse reactions to intrathecal saline injections for control of pain. I Neurosurg 1975; 42:557-561.

117. Manchikanti L. Pharmacology of neuraxial steroids. In: Manchikanti L, Singh $\mathrm{V}$ (eds). Interventional Techniques in Chronic Spinal Pain. ASIPP Publishing, Paducah, KY, 2007; pp 167-184.

118. Benyamin RM, Vallejo R, Kramer J, Rafeyan R. Corticosteroid induced psychosis in the pain management setting Pain Physician 2008; 11:917-920.

119. Manchikanti L, Pampati VS, Beyer CD, Damron KS, Cash KA, Moss TL. The effect of neuraxial steroids on weight and bone mass density: A prospective evaluation. Pain Physician 2000; 3:357366.

120. Altman DG, Schulz KF, Moher D, Egger M, Davidoff F, Elbourne D, Gøtzsche PC, Lang T; CONSORT GROUP (Consolidated Standards of Reporting Trials). The revised CONSORT statement for reporting randomized trials: Explanation and elaboration. Ann Intern Med 2001; 134:663-694.

121. Piaggio G, Elbourne DR, Altman DG, Pocock SJ, Evans SJ, CONSORT Group. Reporting of noninferiority and equivalence randomized trials: An extension of the CONSORT statement. JAMA 2006; 295:1152-1160.

122. Moher $D$, Schulz KF, Altman $D$, for the CONSORT Group. The CONSORT statement: Revised recommendations for improving the quality of reports of parallel-group randomized trials. JAMA 2001; 285:1987-1991.

123. Schulze $C$, Bittorf $T$, Walzel $H$, Kundt G, Bader R, Mittelmeier W. Experimental evaluation of hyaluronidase activity in combination with specific drugs applied in clinical techniques of inter- ventional pain management and local anaesthesia. Pain Physician 2008; 11:877-883.

124. American College of Occupational and Environmental Medicine (ACOEM) Low Back Disorders. In: Occupational Medicine Practice Guidelines: Evaluation and Management of Common Health Problems and Functional Recovery of Workers, Second Edition. OEM Press, Beverly Farms, 2007.

125. Manchikanti L, Singh V, Helm S, Trescot AM, Hirsch JA. A critical appraisal of 2007 American College of Occupational and Environmental Medicine (ACO$E M)$ practice guidelines for interventional pain management: An independent review utilizing AGREE, AMA, IOM, and other criteria. Pain Physician 2008; 11:291-310.

126. Manchikanti $L$, Singh $V$, Derby $R$, Helm S, Trescot AM, Staats PS, Prager JP, Hirsch JA. Review of occupational medicine practice guidelines for interventional pain management and potential implications. Pain Physician 2008; 11:271-289.

127. Manchikanti L, Singh V, Falco FJE, Cash KA, Pampati V. Effectiveness of thoracic medial branch blocks in managing chronic pain: A preliminary report of a randomized, double-blind controlled trial; Clinical trial NCT00355706. Pain Physician 2008; 11:491-504.

128. Manchikanti L, Singh V, Falco FJ, Cash KA, Fellows B. Cervical medial branch blocks for chronic cervical facet joint pain: A randomized double-blind, controlled trial with one-year follow-up. Spine 2008; 33:1813-1820.

129. Manchikanti L, Singh V, Falco FJ, Cash KA, Pampati V. Lumbar facet joint nerve blocks in managing chronic facet joint pain: One-year follow-up of a randomized, double-blind controlled trial: Clinical Trial NCT00355914. Pain Physician 2008; 11:121-132.

130. Manchikanti L, Singh V, Derby R, Helm $S$, Trescot AM, Staats PS, Prager JP, Hirsch JA. Review of Occupational Medicine Practice Guidelines for Interventional Pain Management and Potential Implications. Pain Physician 2008; 11:271-289.

131. Manchikanti L. Evidence-Based Medicine, Systematic Reviews, and Guidelines in Interventional Pain Management, Part I: Introduction and General Considerations. Pain Physician 2008; 11:161-186. 
132. Manchikanti L. Hirsch JA, Smith HS. Evidence-Based Medicine, Systematic Reviews, and Guidelines in Interventional Pain Management: Part 2: Randomized Controlled Trials. Pain Physician 2008; 11:717-773.
133. Manchikanti L, Benyamin RM, Helm S, Hirsch JA. Evidence-Based Medicine, Systematic Reviews, and Guidelines in Interventional Pain Management: Part 3: Systematic Reviews and Meta-Analyses of Randomized Trials. Pain Physician 2009; 12:35-72.
134. Manchikanti L, Singh V, Smith HS, Hirsch JA. Evidence-Based Medicine, Systematic Reviews, and Guidelines in Interventional Pain Management: Part 4: Observational Studies. Pain Physician 2009; 12:73-108. 